Variations sur la lettre, le mètre et la mesure :

Shakespeare

\title{
Stage, page, and the authority of authorship
}

Peter K. Ayers

\section{(2) OpenEdition \\ Journals}

\section{Electronic version}

URL: http://journals.openedition.org/shakespeare/981

DOI: 10.4000/shakespeare.981

ISSN: 2271-6424

Publisher

Société Française Shakespeare

\section{Printed version}

Date of publication: 1 November 1996

Number of pages: 151-164

\section{Electronic reference}

Peter K. Ayers, «Stage, page, and the authority of authorship », Actes des congrès de la Société

française Shakespeare [Online], 14 | 1996, Online since 01 January 2007, connection on 20 April 2019.

URL : http://journals.openedition.org/shakespeare/981; DOI : 10.4000/shakespeare.981 


\section{Variations sur la lettre,}

le mètre et la mesure

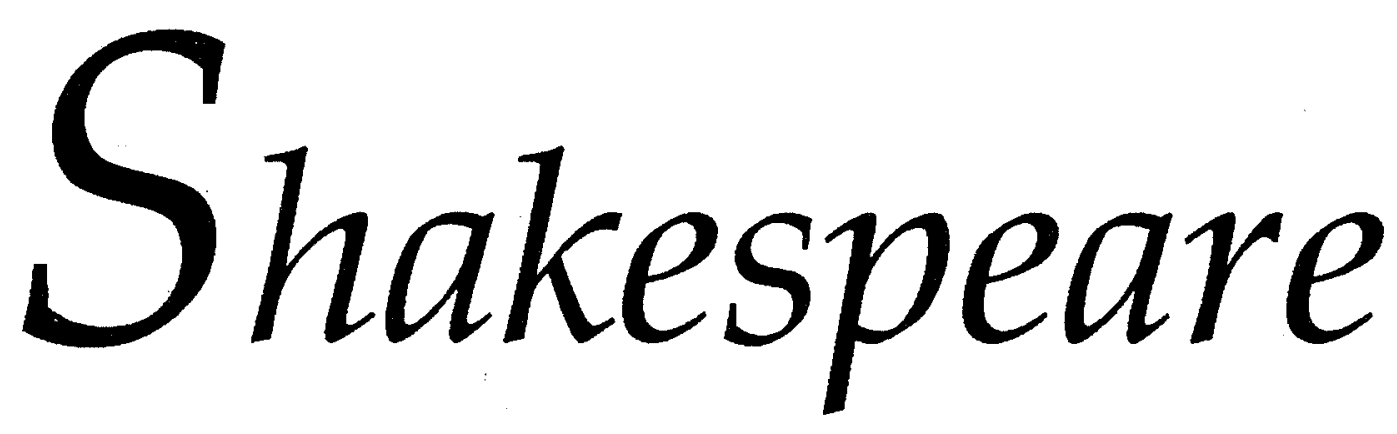

textes présentés par Dominique Goy-Blanquet

Directeur de la publication : Richard Marienstras 


\section{Stage, page, and the authority of authorship Reconsidering The Alchemist and The Malcontent}

In 1616 William Stansby issued The Workes of Benjamin Jonson in folio. Clearly intended by Jonson to be a turning point in the history of the publication of Renaissance dramatic texts, it achieved a success beyond all reasonable anticipation. While much contemporary notice was satirical, the folio was also the recipient of the most sincere sort of flattery, imitation; the first folio of Shakespeare followed in 1623, that of Beaumont and Fletcher in 1647. Wyman Herendeen has recently commented that the folio is "more than a milestone in the history of printing : the physical, economic, social, and literary issues associated with its production alone might occupy a few monographs, or a career."1 Jonson's contemporaries were somewhat less impressed, seeing in the folio conclusive evidence of the overweening pride and literary presumption with which Jonson was more generally charged; as the epigram in Wits Recreations jibes, "Pray tell me $B e n$, where doth the mystery lurke, / What others call a play you call a worke." In more recent years the focus has shifted to the larger implications of Jonson's self creation as "author", and the pursuit of what Richard Helgerson has defined as self crowned laureate status, or Timothy Murray more simply as authorial genius. ${ }^{3}$

With respect to the plays, they, and many others, have noted the degree to which the folio is the culmination of Jonson's attempt to silence or obliterate the ephemeral spoken word of the stage by means of the printed text; while the origins of the texts in the theatre are somewhat grudgingly acknowledged, what is offered is a literary work as divorced from those origins as Jonson can make them. "This Booke, in all numbers, is not the same with that which was acted on the publike Stage", he boasts in "To the Readers" (43-5), appended to the quarto edition of Sejanus. Evidence of collaboration is erased; by the folio, even the earlier allusion to the banished "other pen" in Sejanus has disappeared. The very memory of performance is buried under the weight of literary apparatus; Every Man Out of his Humour, for example, comes complete with Dedication, names of the characters, the first fully developed authorial character sketches in English drama, a choice of endings, and in the quarto, an extended defence of the original version. Negative audience response is acknowledged only as a means of abusing the inadequacies of such spectators; in the Dedication added to the folio text of Sejanus, the play is redefined as a "poeme", one "that (if I well remember) in your Lo. sight, suffer'd no lesse violence from our people here, then the subiect of it did from the rage of the people of Rome" (9-12). In almost every respect, the old democratic, collaborative, commonwealth of the stage, "the players' theater" in Helgerson's phrase, in which actors, management, and audiences no less than dramatists had their share, is succeeded by the absolute authority of the author of the text in a model that can be interpreted as an image of the new, centralized, absolutist political order associated 
with James I's' rule. ${ }^{4}$ Jonson, purveyor of masques for the court, is wrapping his work in the cloak of classical literature to bestow upon himself the authority of authorship, to claim by divine right so to speak, powers never before allowed an English writer, most notably, that of defining both textual meaning and the meaning of text. It is in this context that Richard Newton links him to the "re-invention of the book", and Murray refers to him as "an architect of the printed text - an author in the monumental sense of the term."

Without challenging these views, I wish here to deal with the relationship of the spoken and printed word, and with the nature of the latter more specifically, in a slightly different fashion to that noted above. Two works in particular, Jonson's The Alchemist and John Marston's The Malcontent, will be used in an attempt, not altogether mischievous, to further complicate what is already a very complex subject. The first pertinent example is from IV.5.25-33 of The Alchemist. Here in one sense at least the relationship of stage and page seems clear on the most basic level of typographical layout, with the two parallel texts, one of Dol speaking, the other Face and Mammon, replicating the incoherent babble of the stage, where all speak simultaneously, and to no purpose. The dramatic use of senseless speech drowned out by more of the same is a familiar, indeed characteristic, aspect of Jonsonian dramaturgy, ${ }^{6}$ and here he finds a clever means of translating it from one medium into another. In both, form and content seem happily united. Yet the typographical layout is clever in more senses than one, and transcends in complexity the comparatively simple incoherence of many people speaking at once on the stage. At the very least it draws attention to itself as a textual artifact, one that works in quite a dif ferent way from either that of the surrounding text, or the noise associated with the stage. When several people speak at once, we simply cannot hear what each says with any clarity. Here the words are perfectly distinct, and can be easily read up and down; yet if we do so the point of the layout is lost, since they now make sense and follow a coherent pattern. We cannot, or rather would not, read them systematically in the conventional way, left to right; the jumble of words does not repay the effort. Jonson as author has here created less a textual than a visual artifact, that is, a visual symbol of incoherence that uses text as an medium but denies it the very significance conventionally associated with text. If in the folio he is defining textual meaning, he is here doing so in a most paradoxical fashion, since the passage is not merely devoid of meaningful utterance, but is "about", if anything, its own meaninglessness as a typographical representation of meaningless utterance. The text here establishes only its own duplicity. Jonson is not the first to use the physical shape of text as part of its meaning, and the use of parallel texts, in the form of main text and gloss, is almost as old as writing itself. This, however, is something different. Here we have neither simple cacophony, as on the stage, nor multiple texts engaged in a dialogue with each other, as in a typical glossed work; we have in both a literal and metaphorical sense multiple and competing texts, each distinct and in one sense at least coherent, yet set to work to make the reading and thus coherence of the other impossible. We look at them, but do not in fact read them in the sense the larger text would seem to demand. 
The typographical layout reflected here is a self-conscious device that draws attention to its own cleverness; Jonson is encouraging us to applaud his skill in a kind of typographical special-effects game, and simultaneously discouraging us from reading what he has written with any seriousness. Jonson, showing off his tricks as author, on one level at least undermines the authority that such a status seems intended to confer. Another illustration of the same point is provided by his manifest fascination with the use of different type faces. Sometimes this is straightforward; speech-prefixes, for example, are always capitalized. Jonson also uses ital ics lavishly to give emphasis, to identify words of particular importance and, more generally, the names of characters identified in the text. To the folio text of The Alchemist, however he adds a further flourish, namely the use of black-letter typeface to point to words of Germanic background. Thus Subtle's references to Ulen Spiegal, italic in the quarto, are in the folio black-letter at II.3.32, 249, 269, 315, II.4.47, IV.1.18; Subtle likewise tells Dol in her role as "the great lord's sister" to act "statelich" in black-letter. In the examples above, there is no intention of creating in typographical form the equivalent of a stage effect, or to give any particularly different kind of emphasis than that conveyed by italic type-face; the device seems intended entirely as a self-conscious manipulation of typographical effect for its own sake, again one that encourages us both to applaud the cleverness of the author, and to separate the word itself from its nominal referent. It is an act of self-consciously jokey typographical whimsy, the first such of which I am aware. ${ }^{7}$ However, such playfulness subverts the ostensible authority established by the author, opening up multiple perspectives on a text whose whole apparatus seems at first glance intended to impose authorial fiat. In the first example, the parallel columns of type are impossible to read in a conventional fashion; here we do not read at all, but simply admire the cleverness of the choice of type-face.

These two examples, minor in themselves, suggest a larger paradox, namely that in recasting ephemeral and vulgar diversions for the frivolous into recognizably serious writing through the medium of an authored, and apparently authoritative, folio edition, Jonson is simultaneously using the medium to undermine the authority ostensibly promised by it. In these examples, that is, we are not so much reading Jonson's text as reading Jonson reading Jonson's various texts, and by no means always with a straight face. The Alchemist merely refines a practice evident in almost all his work, namely his fondness for multiple narratives, and multiple layers of text, none of which necessarily tells the same story as any other. Every Man Out provides three different resolutions, grouped differently in quarto and folio, but never in any edition appearing singly, and in the quarto given with their own gloss. Volpone more interestingly does the same thing but on different textual and theatrical levels. The Dedication, accessible only to the reader, offers a sternly moral istic defence of a dramatic resolution that Jonson acknowledges may well be problematic. The epilogue by contrast allows in theatrical terms a reprise for the Fox, who begs our applause by offering us first the tempting but dangerous opportunity to endorse his own role as trickster, and secondly, the less appetizing prospect of "faring jovially", presumably over a meal of mortified, that is rotting, fox. ${ }^{8}$ 
The Alchemist is less blatant in its manipulation of different textual/ theatrical levels, and their subversive possibilities; its apparent attempt to accommodate the tastes of a wide variety of audience and readers has accordingly been praised as Jonson's "apology" for the rigours of Volpone.9 That there is a sting in The Alchemist's tail has been amply and often demonstrated, but as the Royal Shakespeare Company's production of 1992 established yet again, it is one that can be overlooked, with very little effort, by all those who cannot conceive that they themselves might be the object of the play's ridicule. ${ }^{10}$ The textual innovations discussed above, slight as they may seem, have some significance. In their own distinctive fashion, by drawing attention to themselves as unconventional rearrangements of conventional textual systems, they suggest the degree to which the play is about reading itself, about different ways of reading made possible through the medium of print, and about the different kinds of implications contained in different ways of reading. The use of parallel columns of type or of black-letter offer a sardonic and sophisticated reflection of the larger process of printing plays with which the folio is more generally, and apparently more seriously, concerned. They also echo the larger jokes more characteristic of the play proper.

Perhaps the most important of these concerns the subject of alchemy itself. A "scientific" means of perfecting an imperfect natural world, it is of course utterly fraudulent in terms of its literal truth. Yet the illusions created by the alchemists have their own kind of truth, one vindicated by the play itself; Face and Lovewit do manage to turn base metals into gold, and to transform themselves at will. In the process, traditional authority is undermined on every level in a larger celebration of the "modern happiness" announced by Face (IV.1.23); in the urban saturnalia over which they preside, imperfect nature is in one sense at least truly wrought to perfection. ${ }^{11}$ The play is likewise based on a series of illusions that possess their own kind of truth; it too is capable of turning base materials to gold, of both the box-office and printing house kind. The range of London character types set out in the prologue is reflected in the range of characters in the play, who are in the final words of Face linked with the character types of the audience. They too are offered a slightly different variety of "modern happiness" in a similarly seedy urban saturnalia.

Jonson's own suspicions and distrust of the theatre have been frequently noted. ${ }^{12}$ Texts for performance clearly represent a very imperfect kind of nature indeed, one which he seeks throughout his career to purify through the medium of print. The folio represents the final stage of such textual alchemy, one where, as recent studies have shown, every aspect of the edition seems intended, through layout, iconography, and organization, to establish the authority of the author through the authority of a text decked out in full classical regalia. His project, how ever, is drenched in paradoxes. The Alchemist is a profoundly modernist subversion of traditional authority, one in which the stage audience becomes complicit, and for which the applause demanded by Face becomes an involuntary affirmation. The reader's response is likewise rendered problematic. The text can be tricked up to give the illusion of authority, but it is precisely the same kind of illusion that is the play's subject. Jonson seems to be deconstructing the authority of print by divorcing 
its appearance from any conventional meaning it might have, in effect making it its own subject. As with the applause demanded by Face, it is impossible to resist the cleverness of the device, and thus from entering into a willing complicity with the illusion being offered. If Jonson is claiming any authority here, it is less that of a "laureate genius" than of a literary gamester who tantalizes readers with high-stake wagers, but who, after the fashion of Surly, will resort to the "hollow die" and "frail card" to tilt the odds in his favour.

This is a familiar aspect of Jonsonian dramaturgy more generally. In all his plays, as many have noted, the audience is at risk; ${ }^{13}$ Jonson's manipulation of the reader through the medium of print seems to me to be less obvious, but perhaps even more interesting. In his play-texts, that is, the reader is teased and tempted into making a fool of him/herself, led astray, and frequently abused for the ease with which it all happens, in a comedy of affliction not unlike that to which Morose is subjected in Epicoene (a play similarly concerned with inadequate reading practices and the duplicity of text considered as physical artifact).

These conclusions, based as they are on the slender foundation of two examples of typographical inventiveness, might seem both somewhat speculative, and intended to assign to Jonson merely another version of the authorial originality now conventionally attributed to him. To broaden the scope of this inquiry, it is useful to turn to an earlier example by one of Jonson's most interesting contemporaries, John Marston, not perhaps coincidentally his rival, the object of his abuse both verbal and physical, sometime professed friend, and on one occasion at least, collaborator. In April 1604, The Malcontent, originally written for the Blackfriars company of which Marston had recently become a shareholder, was performed by the King's Men under circumstances which, though discussed in the Induction of the play, are still far from clear. ${ }^{14}$ Whatever their nature, the production provided not merely evidence of a wider appeal than his plays are customarily credited with possessing, but the excuse to issue what would become the third quarto version of the play to be printed within the same year. To the corrections made in the second to the first, and the prologue and epilogue added at the same time, there are now provided more corrections, some additional material within the play proper, and the Induction, evidently written by Webster.

Such a lust to get so many versions of the same text into print within so short a space of time might seem excessive in any context, but particularly so in a dramatist who, in the lengthy letter "To the Reader" appended to all three quartos, protested that "only one thing afflicts me, to think that scenes invented merely to be spoken should be enforcively published to be read, and that the least hurt I can receive is to do myself the wrong" (27-30). ${ }^{15}$ Visibly disingenuous, ${ }^{16}$ the explanation seems the necessary defence of a gentleman amateur, the only dramatist of his immediate generation to possess substantial means, and a member of the Inns of Court closely associated with that world's context of sophisticated literary and dramatic endeavour. ${ }^{17}$ Clearly it would not do for such a one to be lumped with merely professional writers. At the same time, however, Marston's explanation draws attention to the complex relation established between the literary and the dramatic texts of the play, Marston's creation of himself as author, and the equally 
complex relation of the author to his readers in ways that perhaps illuminate the is sues discussed above. ${ }^{18}$

The extra-dramatic material that gradually attaches itself to The Malcontent seems important in various regards, beginning with sheer bulk. The printed text in its final form is comprised of a Latin dedication to Ben Jonson, an address "To the Reader", the Induction, a Latin epigraph, a Prologue, a gloss to the Prologue, and an Epilogue. As in the Jonsonian examples above, the extra-dramatic material is used to redefine the relation of writer to reader, and reader to work; the original dramatic text becomes only one of many voices clamouring for our attention, and in some respects not the most important one. One of the central issues touched upon by this material is that of the play's nature; uncertainty concerning the appropriate label to hang on the play is both one of its own subjects, and a clearly anticipated response. Essentially it is a matter of literary classification; while theatre audiences are unlikely to be much interested in it, critical readers for many years have duly played Marston's game, and argued intensely, if largely fruitlessly, about what kind of play it is. Here as elsewhere Marston is both mischievous and promiscuous in his flirtation with genre, tantalizing his readers with hints of revenge tragedy, domestic tragedy, satirical comedy, romantic comedy, the history play, the morality play, and tragicomedy. In the Dedication, he ambiguously refers to the work as "asperam thalium", that is, a comedy that might be either unpolished, or sharp, or both. The "Letter to the Reader" describes it first as a satire, and then as a comedy. In the Induction, Sly simply calls it a "bitter play", while Condell defines it as "neither moral nor satire, but the mean passage of a history" (50-2). In the Stationers' Register it is listed as a tragicomedy.

The matter is of some importance, since different genres assume different values, literary and otherwise, which serve to define the context in which a specific work is to be appropriately understood. Traditionally the darker satirical elements of The Malcontent have been given the greatest emphasis, the result being Parrott and Ball's "incarnation of the pessimistic spirit of the times". More recently it has been customary to focus on the ineffectual nature of villainy in the play and the firm control over events exercised by Altofront/Malevole, and thus to define it as an amusing mixture of comedy and seriousness, as pure comedy, or even burlesque. ${ }^{19}$ To confuse generic labels is by definition to undermine the connection ostensibly existing between the name and the thing being named. That Marston understood, and delighted in, the implications of such generic/linguistic subversion is suggested by the peculiarities of his first significant literary work, The Metamorphosis of Pygmalion's Image and Certain Satires, which provides a notable, and notorious, example; after the erotic narrative poem that provides the first half of the title comes "The Authour in prayse of his precedent Poem" in which the whole production is announced to be a parody of the genre, designed to mock the expectations of "lewd Priapians" (6). ${ }^{20}$ Marston's seriousness in this matter has been much questioned, but the issue seems irrelevant. What is important is the effect of what he is doing; the generic label is now an almost meaningless sign, a signifier that gives no useful information about the signified. The reader's engagement is no longer with the objective reality of the work, whose nature can be duly defined and 
comprehended, but with the apparently arbitrary whims of an author who can choose at will to define, or redefine, the nature and appropriate context of his work, and thus the way it is to be read.

Here the author is a rather different creature from the kind invoked in discus sions of Jonson. Marston, whose plays have been memorably summed up by Alfred Harbage as five-act lapses in taste, ${ }^{21}$ and once described by Samuel Schoenbaum as "fortunate in that his own maladjustment coincided with the malaise of his age", is clearly only a half-hearted aspirant to either genius or laureate status; rather he is a literary ringmaster, one who makes his readers jump through a series of increasingly smaller and higher hoops, a captain of games who defines the rules, marks out the playing-field, and chooses the players, all as he sees fit. Pygmalion's Image, read as an Ovidian epyllon, is clearly that; if, however, reading that way is redefined as the practice of a "lewd priapian", then it is equally clearly a satirical burlesque designed to embarrass and thereby educate just such inadequate readers. Pygmalion's Image suggests another dimension to Marston's authorial gamesmanship. The device unfolded in the "Author's praise" is so transparent, the pretence of seriousness so self-consciously undermined by its arbitrary nature, that a sophisticated reader can only be amused by it; it is a joke in which we are invited to share, if we are clever enough to decode it, to become complicit in the larger game of arbitrarily defining the boundaries of literary reality and illusion for our own amusement.

Marston's literary gamesmanship may be less self-consciously weighty than Jonson's, but it is certainly as competitive. One aspect of this competitiveness is evident in the Dedication of The Malcontent to Jonson, "amico suo, candido et cordato". It represents a public linking of the two individuals under the guise of a private relationship, in a context defined and controlled by Marston, and one in which Jonson is powerless to intervene. Whatever Marston's relations with the man who claimed to have beaten him and taken his pistol, frankness and sincerity would not seem to have been paramount. Marston, in praising Jonson in the terms that he chooses, is both asserting the degree of their kinship as "authors", and defining the terms of his emulation of Jonson's characteristic practices. Another aspect of such gamesmanship is reflected in the implicit dismissal of his own work as "rough comedy". This too is disingenuous, a transparent manipulation of a modesty-topos that suggests selfworth through self-deprecation. It is one of Marston's most commonly used devices. Pygmalion's Image is dismissed as "froth", Antonio and Mellida twice as "the worthless present of my slighter idleness", What You Will as a "slight-writ play", The Fawn as a "slight scene", and The Dutch Courtesan as his "slight hasty labors in this easy play". The series of ironically dismissive dedications that run throughout his work present another variant of the same motif. Obvious examples are those to "Good Opinion" in Pygmalion's Image, the three dedications of The Scourge of Villainy to "his most esteemed, and best beloued Selfe", "Detraction", and "Oblivion", and that of Antonio and Mellida to "Nobody."22 In all of these instances, the reader is being challenged to respond appropriately, that is to say, with the same degree of ironic distance and sophistication that the author himself is demonstrating. The rules of the game are memorably set out in The Scourge 
of Villainy with an off-hand, casual insolence ostensibly disguised as selfdeprecation : "Hee that thinks worse of my rimes then my selfe, I scorne him, for he cannot, he that thinks better, is a foole.' 23

The subversion of genre through the manipulation of literary perspective suggested above is of a relatively obvious nature; Marston, like Jonson, is exploiting the ostensible authority of the author, and the comparative stability of the printed page, to undermine both authority and stability more generally, and particularly those of the text that appears on the printed page. One aspect of The Malcontent, the revenge motif, repays particular attention here. Here again Marston undermines generic convention, this time by creating a resolution in which the villain is simply kicked off-stage. The social and theatrical impropriety of the gesture seems intended both to attract attention and to make the play more resistant to classification.

The resolution of Antonio's Revenge offers an even more striking example. In it Marston self-consciously departs from the most basic convention of revenge drama by having his protagonist, after a particularly bloody and savage act of vengeance, gracefully withdraw to a monastery with the applause of the citizenry ringing in his ears; he no less than the audience is "amaz'd" at a "benignity" (V.3.145) ${ }^{24}$ unique in Elizabethan revenge drama, and one that seems calculated to push the logic of the genre to a conclusion that is intellectually coherent but dramatically, and deliberately, outrageous. If it is necessary for the protagonist to bring order into the world by killing villains, then it must be right for him to do so, and there is no need for him to be killed off in the conventional fashion; the usual tragic resolution is in this context a wishy-washy compromise for those who want to have their revenge cake and eat it too. As with earlier works, it is a very knowing, ingroup, jokey, way of asserting authority; if subsequent critics have been less amused than those for whom Marston was writing, then that is probably because they are, in his terms, simply yet another group of inadequate readers.

Antonio's Revenge, considered as a text, appears almost naked, equipped only with a prologue in the way of authorial intrusion. The final version of The Malcontent comes to the reader more fully clothed with an apparatus that provides very clear, if indirect, guidelines for an audience now defined as readers rather than spectators. The most important of these rules for reading, clearly, is to respect the right of the author to define, however arbitrarily and inconsistently, the nature of the game being played. The bulk of "To the Reader", like that of the Prologue, is made up of an attack on those who "have been most unadvisedly cunning in misinterpreting me, and with subtlety as deep as hell have maliciously spread ill rumors" (13-15), that is, who have wrongly read the rulebook. ${ }^{25}$ Marston here and elsewhere anticipates Jonson's exploitation of print as a medium that allows the dramatist to escape the comparative anonymity of the stage by intruding himself between page and reader in order to define, not so much "meaning" per se as the conditions under which the text is to be read.

The subversive and anti-authoritarian implications of such a presentation of authorship are, as with The Alchemist, themselves in part the subject of the play. 
Altofront before his overthrow was, he suggests to Celso, something very much like the ideal prince of Elizabethan convention who has read too much Tillyard :

My throne stood like a point in midst of a circle,

To all of equal nearness, bore with none,

Reigned all alike, so slept in fearless virtue.

Yet as the last line suggests, and the rest of the speech confirms, such an idealist reliance upon conventional values and the metaphysical authority associated both with them and his position is folly. As he goes on to comment, he was

Suspectless, too suspectless: till the crowd
(Still lickerous of untried novelties),
Impatient with severer government,
Made strong with Florence, banished Altofront.

The passage outlines in singularly compressed form the birth of the early modern age, the urban Iron Age celebrated variously in much of Jacobean drama. Altofront in his shifting roles creates what is in effect an exemplary new-historicist textbook, teaching the astute reader that authority is an illusion created by the clever writer of cultural/political artifacts, accepted as such by the sophisticated reader, and taken for reality only by the naive. As deposed duke, railing satirist, malcontent revenger, other-worldly moralist, machiavellian intriguer, and finally agent of order restored, he is the duplicitous author of a wide range of unreliable texts, traversing an equally wide range of potential genres, all of which are defined in terms of their inadequacy. As satirist, for example, he duly lashes the corruptions of the court in the outraged voice of the traditional moralist, only to create a disguise that gives him room to manœuvre as a comic spectacle. As disillusioned moralist, he knows that to know the world is to wish to leave it, and duly persuades Pietro to renounce his office and retreat to a hermit's cell with the kind of contemptus mundi earlier articulated by the revengers of Antonio's Revenge :

Think this - this earth is the only grave and Golgatha wherein all things that live must rot; 'tis but the draught wherein the heavenly bodies discharge their corruption; the very muck-hill on which the sublunary orbs cast their excrements. Man is the slime of this dung-pit, and princes are the governors of these men.(IV.5.110-15)

Here, however, it is merely a device, a rhetorical set-piece, one more unreliable text among many; Altofront persuades Pietro to withdraw from this muck-hill largely so that he may reassume his place on it.

Altofront's painful education provides as well the context for the peculiarities of the resolution. It has provoked a wide variety of responses, being held up both as 
a triumph of civilized and civilizing morality over the primitive lust for retribution, and as a flaw in the moral design of the play. ${ }^{26}$ Neither extreme seems entirely adequate. On the one hand conventional punishment would be thematic nonsense, and would certainly destroy the fragile balance in which the play hangs suspended by introducing a gravity of action to match the gravity of language; on the other, the new pattern of civilized harmony established by the resolution is defined by its instability. Mendoza goes without punishment, Ferneze's penitence is revealed as fraudulent, Maguerelle merely shifts her business location, Bilioso remains untouched by either punishment or enlightenment, and the triumphant Altofront defines his new role of restored duke as being no more substantial than any of those previously played.

As with most of Marston's resolutions, not the least part of this one would seem to be its deliberate attempt to thwart conventional generic expectations. One aspect of this is reflected in the peculiar mixture of seediness and iconoclastic exuberance that informs the latter part of the play. To live in a world where Bilioso is the norm, and thus where the example of virtue and the reproof of vice are equally irrelevant, may be squalid, but is also by the same token immensely liberating; anything goes, and the moral zeal of satire turns inevitably to a saturnalian release that if neither pastoral not idyllic, marks at least a working accommodation with the degradation that defines human existence. Sadder but wiser, dukes, revengers, satirists, fools, and machiavellian villains can all agree to disagree as to both means and ends, shake hands, and get back to their various businesses. Altofront, having learned that the prince occupies but "A jailor's office to keep men in bonds, / Whilst toil and treason all life's good confounds" (IV.5.117-18), will return to take up his duties, and the others will come along too.

The movement enacted within The Malcontent from satire to saturnalia renders old literary classifications, and the values associated with them, irrelevant. The result is a kind of exuberant anarchy, a revenger's holiday where nothing is as it seems, where the only consistent principle of signification is instability. It is a thematic movement that is duplicated in the self-conscious theatricality of the play, in its emphasis, that is, upon the unreality of the medium; in Altofront's final words the dream from which Mendoza is so violently awakened simply spreads outward to embrace both performers and audience in the world of visions, dreams, and illusions :

The rest of idle actors idly part, And as for me, I here assume my right, To which I hope all's pleased. To all, good night.

(V.6.165-67)

It is also a movement enacted on another level of the play as well, namely in the transformation effected by the apparatus of The Malcontent from stage play to literary text. The accretions earlier discussed in one context serve a variety of other functions : they both draw attention away from the basic work itself towards its 
status as a self-conscious, self-reflexive artifact, and provide a more technological dimension to the shift from objectivity to subjectivity. Drama, however "dreamlike" it may be in the context invoked by Altofront, is defined by its public and communal nature, its impersonality, and in that sense at least, its objectivity. We all see and hear the same things, which are limited to the actions and the words of the characters on stage; there is no narrator to tell us what such things mean, and while our interpretations of them may vary widely, they are based on facts upon which we can all more or less agree. A literary text, however, is read privately, and the presence of a narrator, implicit or explicit, necessarily turns its focus from the objective and commonly perceived facts of a staged performance to the subjective responses of an individual reader interpreting the narrator's presentation of such facts. By the third quarto, we are reading Marston reading Webster and Marston reading Marston reading The Malcontent. ${ }^{27}$

The various texts of The Alchemist and The Malcontent are of particular interest not least because they suggest that the appearance of an "author's theatre", together with the texts so authored, is a more complex and varied business than the monumental status of Jonson's folio, together with the various commentaries it has generated, might lead us to believe. The strategies deployed within and around these texts seems designed as much to destabilize authority as to assert it; the literary gamesmanship of Marston and Jonson as "authors" reflects perhaps the ironic recognition that such authorship does not and cannot bestow authority. To accept them, or their texts, as "authoritative" is to deserve to be censured by an authority revealed to the sophisticated as spurious; to see through them is to be accepted into a different sort of relationship as "reader", in which we are challenged to compete rather than to submit. In other words, the rules for reading, implicit or explicit, established by both plays become only one text among many, and by that token no more reliable than the others.

In both cases, their authors are relinquishing authority as much as asserting it; well before their time, they seem to have understood that the material stability of the printed text creates the conditions of reading that guarantee its hermeneutic instability. The control of interpretation suggested by Helgerson, Murray, Rowe, and others is in this context as much a surrender as a conquest. To fail to see that there are any rules is of course to label oneself a fool, but equally to follow them too assiduously is to do no less. Ultimately the only real rule seems to be to accept the author's right to challenge the reader to compete in a peculiarly sophisticated literary contest, in which the wise reader will realize that he or she can only win metaphorically by acknowledging the impossibility of winning literally. In The Malcontent, Altofront, the author, director, and chief actor in his own drama, dissolves in his final lines his fiction of control; Jonson and Marston, notable authors of the dramatic author, seem here to be doing much the same.

Peter K. AYERS

Memorial University of Newfoundland 
1 Ben Jonson's 1616 Folio, ed. Jennifer Brady and W. H. Herendeen, Newark, U. of Delaware Press, 1991, p. 11

2 Quoted by C. H. Herford, Percy and Evelyn Simpson, in Ben Jonson, 11. vols., Oxford, Clarendon Press, 1925-52, vol. 9, p. 13. All subsequent textual references to Jonson are from this edition.

3 Richard Helgerson, Self-Crowned Laureates: Spenser, Jonson, Milton and the Literary System Berkeley, U. of California Press, 1983, pp. 110ff; Timothy Murray, Theatrical Legitimization: Allegories of Genius in Seventeenth-Century England and France, Oxford U. P., 1987, chaps. 3-4.

4 See especially Richard Helgerson, Forms of Nationhood: The Elizabethan Writing of England, U. of Chicago Press, 1992, pp. 197-202.

5 Richard Newton, "Jonson and the (Re-)Invention of the Book," in Classic and Cavalier : Essays on Jonson and the Sons of Ben, ed. Claude J. Summers and Ted-Larry Pebworth, U. of Pittsburgh Press, 1981, pp. 91-104; Murray, p. 51; see also George E. Rowe, Distinguishing Jonson : Imitation, Rivalry, and the Direction of a Dramatic Career, Lincoln, U. of Nebraska Press, 1988,. pp. 38-67.

6 The vapours game of Bartholomew Fair, where the only rule is to contradict the previous speaker, is an obvious example.

7 Though the use of black-letter and roman fonts to distinguish different textual systems in the same work, most commonly of main text and gloss, is by no means uncommon, this seems of a quite different order.

8 See James A. Riddell, "Volpone's Fare", Studies in English Literature 21, 1981, pp. 307-9. The Royal National Theatre's 1995 production cut the epilogue entirely, offering in its place a much more sentimental stage picture of Mosca being whipped and Volpone languishing, unchained, in a spacious cell.

9 See A. W. Lyle, "Volpone's Two Worlds", Yearbook of English Studies 4, 1974, p. 76; David Bevington, "Shakespeare vs. Jonson on Satire", Shakespeare 1971, ed. Clifford Leech and J. M. R. Margeson, U. of Toronto Press, 1972, p. 110.

10 In this production, the main emphasis was upon good-natured farce; Lovewit was portrayed as an amiable but harmless old gentleman who stumbles happily upon unexpected good fortune in the form of both wife and wealth. 
11. For a fuller treatment of this issue, see P. K. Ayers, "Staging Modernity : Chapman, Jonson, and the Decline from the Golden Age", Cahiers Elisabéthains 47, 1995, pp. 9-28.

12. See Jonas Barish, "Jonson and the Loathèd Stage", A Celebration of Ben Jonson, ed. William Blissett, Julian Patrick, and R. W. Van Fossen, U. of Toronto Press, 1973, pp. 27-54.

13 See in particular Douglas Duncan, Ben Jonson and the Lucianic Tradition, Cambridge U. P., 1979, passim.

14. For the fullest discussion of the matter, see The Malcontent, ed. G. K. Hunter, The Revels Plays, Manchester U. P., 1975), xxviii-xxx; xli-liv. All references are to this edition.

15 The same point is made again in The Fawn: : « If any should wonder why I print a comedy, whose life rests much in the actor's voice, let such know that it cannot avoid publishing. Let it therefore stand with good excuse, that I have been my own setter out »("To My Equal Reader," pp. 20-24).

16 The extreme care taken in the preparation of texts for the printer, the extensive press corrections, the frequent Latin stage directions, and the critical apparatus of letters filled with classical quotations and allusions all suggest that Marston no less than Jonson regarded his plays as "works" worthy of literary attention.

17 For the fullest account of this context, see Philip Finkelpearl, John Marston of the Middle Temple, Cambridge, Mass., Harvard U. P., 1969, pp. 3-80.

18 Marston, even in these very un-Jonsonian disclaimers, makes the very Jonsonian point that his plays' essence is to be grasped through their language, rather than through the more vulgar context of spectacle. For an interesting discussion of the same issue in the context of Webster, see Mary A. Blackstone and Cameron Louis, "Towards 'A Full and Understanding Auditory' : New Evidence of Playgoers at the First Globe Theatre", Modern Language Review 90, 1995, pp. 55659.

19 T. M. Parrott and R. H. Ball, A Short View of Elizabethan Drama, New York, Scribner's 1943, p. 155; see also Anthony Caputi, John Marston, Satirist, Ithaca, Cornell U. P., 1961, pp. 181-98; Martin Wine, ed. The Malcontent, Regents Renaissance Drama, London, Edward Arnold, 1965, p. xvii; R. A. Foakes, "On 
Marston, The Malcontent, and The Revenger's Tragedy," Elizabethan Theatre VI, ed. George Hibbard,Toronto, Macmillan, 1978, pp. 65-72.

20 The Poems of John Marston, ed. Arnold Davenport,Liverpool U. Pr., 1961.

21 S. Schoenbaum, "The Precarious Balance of John Marston," PMLA 67 (1952), 1078; Alfred Harbage, Shakespeare and the Rival Traditions, New York, Macmillan, 1952,p. 244.

22 These look forward to the equally theatrical inscription of Marston's gravestone, Oblivioni sacrum, which shows the same ostentatious self-effacement. It seems unlikely that Marston would have been gratified by the literal fulfilment of the wish brought about by bombs in World War II.

23 "To those that seeme iudiciall perusers" (35-36). Only slight less truculent are the further rules that follow: "If thou perusest me with an vnpartiall eye, read on; if otherwise, knowe I neyther value thee, nor thy censure" (38-40).

24 Antonio's Revenge, ed. G. K. Hunter, Regents Renaissance Drama Series, Lincoln, U. of Nebraska Press, 1965.

25 Patrick Buckridge has recently written most interestingly and in a similar context on Marston's use of the mise en abyme in The Metamorphosis of Pygmalion's Image and Certain Satires to direct his readers; he suggests that Marston is instructing them them how to read his satire as a form of fiction, rather than as a code to be cracked to find its literal application. It is clearly a productive way of approaching Marston's work more generally, though Buckridge perhaps neglects the element of gamesmanship involved. See "True Reading and How to Get it: John Marston's Primer for Satire," Southern Review 23, 1990, pp. 58-67.

26 See Bernard Harris, ed. The Malcontent, New Mermaids, London, Ernest Benn, 1967, p. xxx; J. Peter, Complaint and Satire in Early English Literature, Oxford U. P., 1956, p. 238.

27 Richard Wollman has recently discussed Donne's disinclination to see his poetry published in terms of an attempt to control interpretation, or limit misinterpretation, by restricting access to the circle of his acquaintances, who then in turn become responsible for its wider reception. See " 'The 'Press and the Fire' : Print and Manuscript Culture in Donne's Circle", Studies in English Literature 33, 1993 , pp. 86-97. It seems highly likely that Marston's often-voiced concern with misinterpretation springs no less from his awareness of the larger implications of his rush to print than his frequent brushes with displeased authority. 